\title{
頭頸部領域の粘膜悪性黒色腫症例
}

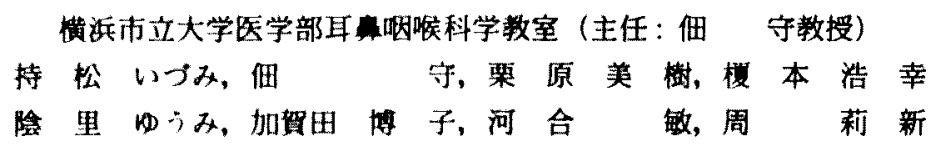

CASE REPORTS OF MUCOSAL MELANOMA OF THE HEAD AND NECK

IZUMI MOCHIMATSU, M.D., MAMORU TSUKUDA, M.D., MIKI KURIHARA, M.D. HIROYUKI ENOMOTO, M.D., YUUMI KAGESATO, M.D., SATOSHI KAWAI, M.D. and ZHOU LI XIN,

Department of Otorhinolaryngology, Yokohama City University, School of Medicine, Yokohama

Twelve patients with mucosal melanoma in the head and neck were treated at Yokohama city University from 1975 to 1994.

The sex distribution was 5 male and 7 female, and the age ranged from 40 to 79 year-old. The highest number of patients were in their sixties. In 10 cases tumors arose in the nasal cavity, in one case in the maxillary sinus and in the other case in the oral cavity.

The treatment modality for this tumor consisted of various combination therapies including surgery, radiotherapy, chemotherapy and immunotherapy. Combination chemotherapy consisting of dimethyltriazeno imidazole carboxamide (DTIC, Dacarbazine), amino methyl pyrimidinyl methyl chlorethyl nitrorosourea hydrochloride (ACNU) and vincristine (VCR). Cisplatin (CDDP) was recently used for cases where other chemotherapy was not effective. Surgical treatment in the initial therapy was performed in 8 patients. In three of these 8 cases, the surgical margin was positive. One of them was dead after 9 months, another dead with complication after 1 year and the other survived free of any tumor.

Immunotherapy using OK 432 , interleukin -2 , LAK therapy and low dose CPM was effective for some patients.

The 5-year survival rate was $44 \%$. Patients with surgical treatments in the initial therapy had longer survival than those without surgical treatments.

Key words : mucosal melanoma, head and neck, treatment and prognosis

A $99-0552-91399$

はじめに

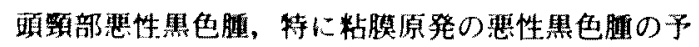
後は不良て、5 年生存染は11 26\% ${ }^{1)-71}$ と報告されて

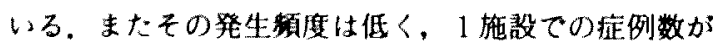

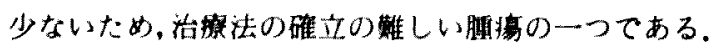
われわれは1975年から1994年まての20年間に当教室に

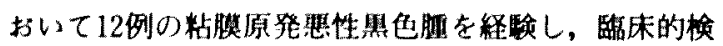

暷とともに若干の文献的考察を行ったので報告する.

対象及び結果

1. 対象

対象は1975年から1994年まての20年間に当教室を初 埥し、入院治港をした粘膜要性黑色腫症例で男性 5 例， 女性 7 例の計 12 例である（表 1 ）。年齢分布は40歳から 
表 1 症 例

\begin{tabular}{|c|c|c|c|c|c|c|}
\hline 症 例 & 性 & 年 齡 & 初䛦までの期間（M) & 主 訴 & 初発部位 & Stage ${ }^{*}$ \\
\hline 1 & F & 51 & 6 & 鼻内腫㴼 & 左鼻腔 & I \\
\hline 2 & F & 78 & 10 & 鼻出血 & 右鼻腔 & I \\
\hline 3 & $\mathrm{~F}$ & 53 & 6 & 鼻出血 & 右番腔 & I \\
\hline 4 & $M$ & 48 & 0.5 & 鼻 閉 & 左鼻腔 & I \\
\hline 5 & F & 79 & 0.5 & 番出血 & 右番腔 & II \\
\hline 6 & M & 54 & 4 & 鼾出血 & 左鼻腔 & I \\
\hline 7 & M & 73 & 6 & 䫫部嗹痛 & 口蓋 & III \\
\hline 8 & M & 53 & 0.5 & 鼻出血 & 左鼻腔 & II \\
\hline 9 & $\mathrm{~F}$ & 45 & 1 & 歯 痛 & 左上霣洞 & I \\
\hline 10 & M & 67 & 7 & 鼻出血 & 右鼻腔 & I \\
\hline 11 & F & 68 & 1.5 & 鼻 閉 & 左鼻腔 & I \\
\hline 12 & F & 40 & 3 & 鼻出血 & 左鼻腔 & I \\
\hline
\end{tabular}

* Ballantyneの Staging に準じて分類

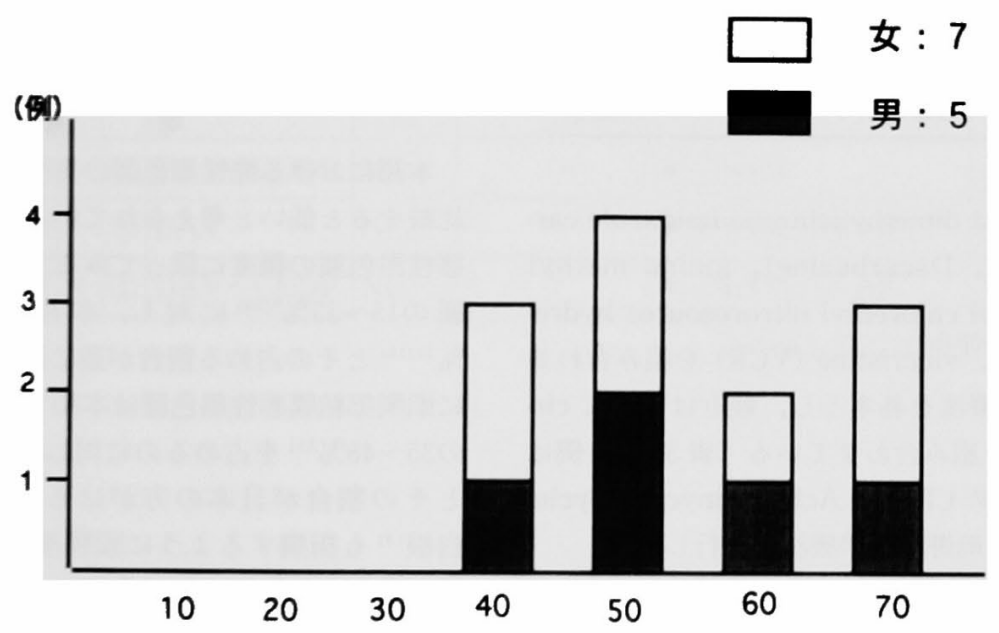

图 1 年齢と性別

79歳に及び, 平均は59歳であった(図 1)。発生部位は 整が10例で，上額洞っ上びロ蓋が各 1 例ずつであっ た(表 1 ).

主訴は鼻腔が多いため奥の症状が多いが，その中て 特に鼻出血が目立った（表 1)。受診までの期間は全例 1 年以内であった（表 1 ).

病期分類は Ballantyne ${ }^{8)}$ の提唱した頭顒部 3 段階 の分類を使用した。この分類によると Stage I が最も
多く9例であった(表 1 ).

\section{2. 治療}

初回治療において手術を施行したのは 8 例でこのう 5 5 例は化学撩法と免疫療法を組み合わせた。そのう ち 1 例は放射線の腔内照射も加えた。手術を施行しえ なかった 4 例の内訳は，合併症のためが 2 例，頸部転 移があり en block の切除不能と考えた 1 例, 肺転移例 1 例であった（表 2 ). 
带 2 初回治源

\begin{tabular}{|c|c|}
\hline 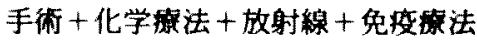 & 1 \\
\hline 手術＋化学撩法＋免疫寮法 & 4 \\
\hline 手術＋放射線＋免疫療法 & 1 \\
\hline 手術十免存䆖法 & 2 \\
\hline 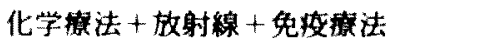 & 1 \\
\hline 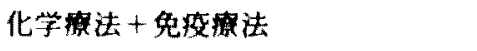 & 1 \\
\hline 免投法法のみ & 2 \\
\hline
\end{tabular}

衰 3 化学棈

$\begin{array}{ll}\mathrm{DTIC}+\mathrm{ACNU}+\mathrm{VCR} & 3 \\ \mathrm{DTIC}+\mathrm{ACNU}+\mathrm{VCR}+\mathrm{CDDP} & 3 \\ \mathrm{CDDP}+\mathrm{THP}-\mathrm{ADM}+\mathrm{CPM} & 1\end{array}$

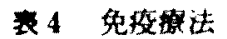

\begin{tabular}{ll}
\hline BCG & 3 \\
OK432 & 3 \\
$\mathrm{IL}-2+\mathrm{LAK}$ & 2 \\
$\mathrm{OK} 432+\mathrm{LAK}$ & 1 \\
$\mathrm{IL}-2+\mathrm{OK} 432+\mathrm{LAK}$ & 1 \\
$\mathrm{BCG}+\mathrm{PSK}$ & 1 \\
$\mathrm{BCG}+\mathrm{PSK}+\mathrm{OK} 432$ & 1 \\
\hline
\end{tabular}

化学䃄法の内容は dimethyltriazeno imidazole car. boxamide (DTIC, Dacarbazine), amino methyl pyrimidinyl methyl chlorethyl nitrorosourea hydrochloride (ACNU), vincristine (VCR)を絸み合わせ

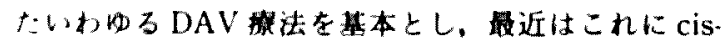
platin (CDDP) を利加合わせている（捗 3)。1例は 当初腺嘌疑いのため CDDP, Aclasinomycin, Cyclo. phosphamide の多剂搠用化学撩法を施行した。

免疫撞法は全例に施行した。1984年以前はBCGを 用いていたが、それ以降は OK-432 を使用し，㛫合に より interleukin-2 (IL-2) で活性化した自己リンパ球 の移入, いわゆる lymphokine activated killer (LAK) 細胞の移入6組み合わせている（表 4)。

3. 結果

手術は 8 例に施行しサージカルマージンは肉眼的 に最低 $10 \mathrm{~mm}$ 栍確保した。このうちサージカルマージ ン陰性であったのは5例であった。これの予後は症 例10と1102 例は再発なく生存, 症例 3 は1年後に再 発したが手術と放射線で13年間再発を見なかった。し かしその後再発, 初路より17年後の現在担舴状慗てあ
るが生存中である。症例 1 はやはり 1 年後に再発，そ の後数回の手術を経て初影より17年後に死亡した。应 例 4 は初影より36週で来院せず予後は不明であるが， この時点ては再発は諰められなかった。一方サージカ ルマーシンン晹性の 3 例は 1 例（症例 5 ）が9 力月て死 亡し，他の 1 例（症例 9）は脳梗塞て 1 年後に死亡し た. 残りの1例（症例12）は現在肉眼的な腫癔は哂め

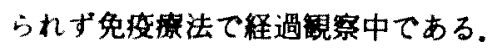

化学僚法を施行した 8 例のうち 1 例任手術後なので 評価不能であった，残りの7例は放射線後施行した 1 例のほかはすべて no change（NC）であった。

放射線治挜は 3 例に施行したか，1例は術前に 34Gy 行い手術標本は no neoplasmであった. 他の1 例は奻果なく、またもう1例は術後の腔内照射である。

免投独法は篻独投与の症例がないので判定不能であ ろが、症例 8 は化学㟟法ては効果が見られなかったが, IL-2,OK432 の全身ならびに局所投与と低量の Cyclophosphamide (CPM, $\left.300 \mathrm{mg} / \mathrm{m}^{2}, 1 / \mathrm{M}\right)$, LAK 療法 て30力月の生存を得た（表 5 ).

Kaplan-Mayer 法での生存 5 年生存率は $44 \%$ であ った(図2)。

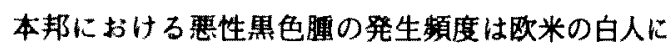

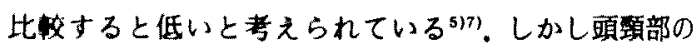

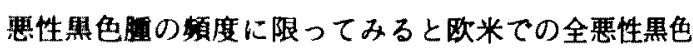
肠の15 33\% ${ }^{\text {甲100 }}$ に対し，本邦の報告ては33〜56 $\%^{(112)}$ とその占める割合が逆に高くなっている.さら

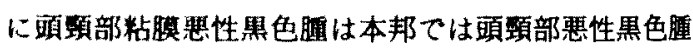
の35〜 48\%"光占めるのに対し欧米では2.7〜 7.6\%" とその割合が日本の方がはるかに高い。すなかち 白根 ${ }^{3)}$ も指摘するように頭頸部に発生する悪性黒色 腢は欧米てはほとんどが皮间に発生するのに対し，本 邦ては1/3から半分近くが粘膜に発生していると推察 される.

発症年鉿は60歳代にピークがあるとの報告が多く， 次に50咸代が繶きこの年䏩展で半分以上を占め

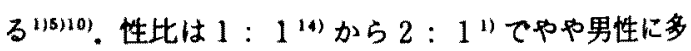
いと考えられている゙

発生部位別にみると Conley ${ }^{1)}$ 汕口腔が50\%,ついて

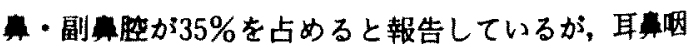
喉科医の報告てはむしろ息・副㫷腔発生率が高いよう てある゙(3).小村")らは両者てほとんど差がなかったと

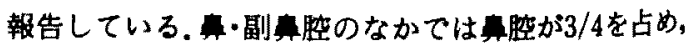


表 5 初回治㞠後経過

\begin{tabular}{|c|c|c|c|c|c|c|c|c|c|c|c|}
\hline \multirow{2}{*}{ 症 } & \multicolumn{3}{|c|}{ 手 術 } & \multicolumn{3}{|c|}{ 化学涚法 } & \multirow{2}{*}{\multicolumn{2}{|c|}{ 放射線 }} & \multirow{2}{*}{\multicolumn{2}{|c|}{ 兔疫滰法 }} & \multirow{2}{*}{$\begin{array}{r}\text { 予後（生存月数） } \\
\text { (死因) }\end{array}$} \\
\hline & & 手術名 & & & 種類 & 効果 & & & & & \\
\hline 1 & (1) & 上額部分切除 & - & & & & & & (2) & $\mathrm{BCG}$ & $\begin{array}{l}\text { 死亡（208） } \\
\text { (膇転移) }\end{array}$ \\
\hline 2 & & & & & & & & & & BCG, OK432, PSK & $\begin{array}{l}\text { 死亡 } \quad(6) \\
\quad(\text { 肺転移) } \\
\end{array}$ \\
\hline 3 & (2) & 上預部分切除 & - & & & & (1) & $\begin{array}{r}\text { リニッッ } \\
(34 \mathrm{~Gy})\end{array}$ & * & OK432 & 再発生存 (210) \\
\hline 4 & (1) & 上預部分切除 & -16 & (2) & DAl & & & & (3) & BCG, PSK & 不明 （36） \\
\hline 5 & (2) & 上疑部分切除 & + & & & & & & (1) & BCG（全身・局所） & $\begin{array}{l}\text { 死亡 } \quad(9) \\
\quad \text { (肺転移) }\end{array}$ \\
\hline 6 & & & & (2) & DAV & $\mathrm{PR}$ & (1) & $\begin{array}{r}\text { テレコバルト } \\
(50 \mathrm{~Gy})\end{array}$ & (3) & $\mathrm{BCG}$ & $\begin{array}{l}\text { 死亡 (11) } \\
\text { (肺転移) } \\
\end{array}$ \\
\hline 7 & & & & & & & & & & IL-2, LAK & $\begin{array}{l}\text { 死亡 (2) } \\
\quad \text { (肺転移) } \\
\end{array}$ \\
\hline 8 & & & & (1) & DAV + CDDP & $\mathrm{NC}$ & & & (2) & $\begin{array}{l}\text { IL-2, OK432, CPM, } \\
\text { LAK (全身・局所) }\end{array}$ & $\begin{array}{l}\text { 死亡 } \quad(30) \\
\quad \text { (肺転移) }\end{array}$ \\
\hline 90 & (2) & 上䫝部分切除 & -10 & & CAP & $\mathrm{NC}$ & (3) & $\begin{array}{r}\text { 空内 } \begin{array}{r}(30 G y) \\
\text { (術後) }\end{array} \\
\end{array}$ & * & OK432 & $\begin{array}{l}\text { 死亡 (12) } \\
\quad \text { (脳梗塞) } \\
\end{array}$ \\
\hline 10 & (2). & 上頻部分切除 & -18 & (1) & $\mathrm{DAV}+\mathrm{CDDP}$ & $\mathrm{NC}$ & & & * & OK432 & 無再発生存 (24) \\
\hline 110 & (2) & 上預部分切除 & -10 & (1) & DAV & $\mathrm{NC}$ & & & * & OK432, (3)LAK & 無再発生存 (23) \\
\hline 128 & (2) & 上預新行切除 & +10 & (1) & $\mathrm{DAV}+\mathrm{CDDP}$ & $\mathrm{NC}$ & & & * & OK432, (3)LAK & 無再発生存 (19) \\
\hline
\end{tabular}

(1)、(2)，(3)：治撜順位，*：同時併用

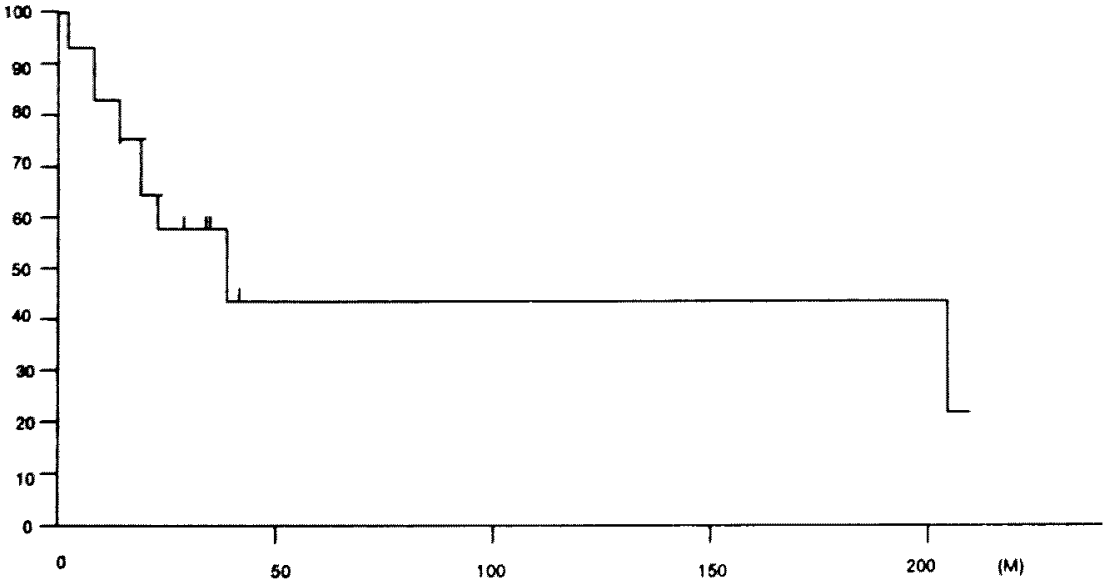

图 2 生存曲線（Kaplan-Meier 法） 
主訴は算の埸合は閉・出血が多数例て見られて

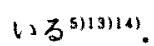

要性黒色徆の治療は目頭にも述へたように確立され たものがなく、それぞれの施設が武行錯誤しているの が現状てある。基本的には手術可能な应例に対しては 手術を主治浿とする施設が多い.Conley"は口望・

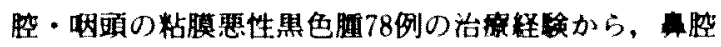

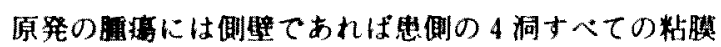
を、中央にあれば両側の洞粘脕すべてを除去すべきで あると主张している、これはこの成復が multi centric originであるとの考えに基ついている. Freedman ${ }^{151}$ もなるべく多くの粘腅を除去すべをとの考えを述へて いる.今回の症例の中にも，手衙本てマージン除性

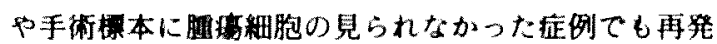
しており、手術に際しては十分な粘䭪除去が必要で り，注意梁い追跡が必要七考之られた。生た Lee' この疾患は局所のコントロールが重要であり，局所再 発によって轻移か誘発され、サルベージ手術を中心と した再発後の治療成績は悪く, 初回治哾てのしっかり した局所コントロールの重要性を指摘していろ.今回 の検討でも手術が可能て, 手術が行えた症例の予後が 良いとの結果であった。

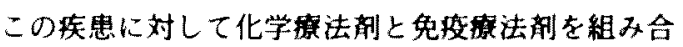
わせた治㞠が手街に次いで用いられている。特に転移 などによって手術が不可能な例ては免度・化学㧺法が

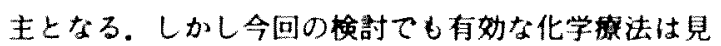
いだせず，今後の棵题上いえる，また免疫抾法はIL-2 の局所または全身投与と抗脸侽性エフェクター細胞の

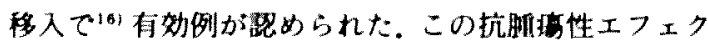

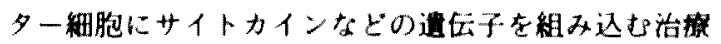

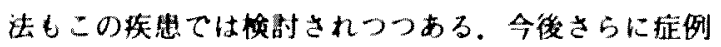

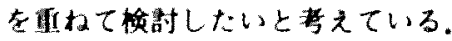

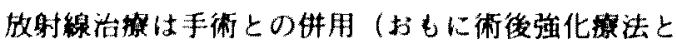
して）お゙よび手術不能例に施行しているものが多い. 单独ての有奻(列は期待できなが，最近 Kingdom ${ }^{27}$ らは術後照射により無病期間と予後を向上出来たと報 告している.

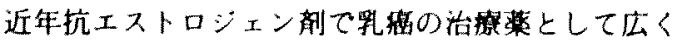
使われているTamoxifen と化学撞法郕の併用撩法が 注目されている.これについては1984年にDel Prete ${ }^{(8)}$ らが BCNU, CDDP, DTIC との組み合わせて20人の 転移性黑性照色随で好等55\%と報告し，さらに1989 年に McClay ${ }^{191}$ が奏效率51\%と報告をして以来注目 されるに至った. Tamoxifen は estrogen receptor を
表出していない遇疸にも奻果を認め，さらに組み合わ せる化学䒚法剂と相乗奻果を示すというものてある。

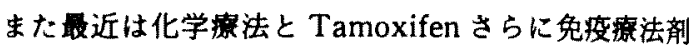
を重ねたレジメが考案されている201. しかし奏奻率は 40〜50\%と高いが副作用が強く，無病期間が短いため 決定的な治痖法としては確立されていないのが現状て ある.

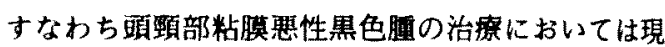
時点では単独治獠で有奻なものにはそしく，小村らも 指摘するように㹡大手術を主体とし放射線,化学垬法， 免疫瘄法を加えた策学的治痖が必要と考えられた。

\section{まと め}

1975年から1994年の 20 年間に12例の頭頙部粘膜悪性 黑色腫の治滰を行った。これらを険討した結果次のよ うな知見を得た。

1. 20 年に12例の頭頸部粘膜要性黒色腫を経験し た.

2. 性差はやや女性に多く，年齢のピークは50歳代 ておった。

3. 原発部位は㸆が大部分を占め、主訴は算出血 が多かった。

4. 有効な化学撩法は見いだせなかった。

5. 免疫庰法の奻果は単独では判定できなかった が，LAK 撞法て延命を認めた症例があった。

6. 5 年生存率は $44 \%$ であった。

7. 予後は手術施行例の方が良好であった。

8. 䫓项部粘膜孯性黑色腫の治港においては現時点 では策独治港は有効なものには乏しく，拡大手術を主 体とし放射線，化学療法，免疫癔法を加えた集学的治 掊が必要と考えられだ。

\section{文㰴}

1) Conley JJ : Melanomas of the Mucous Membrane of the Head and Neck. Laryngoscope 98 : 1248-1254, 1989.

2) Eneroth $\mathrm{CM}$, Lundberg $\mathrm{C}$ : Mucosal malignant melanomas of the head and neck with special reference to cases having a prolonged clinical course. Acta Otolaryngol $80: 452-458,1975$.

3) Shah JP, Huvos AG, Strong EW: Mucosal Melanomas of the Head and Neck. Am J Surg 134: 531-535, 1977.

4) Berthelen A, Andersen AP, Jensen TS, Hansen HS: Melanomas of the Mucosa in the Oral Cavity and 
the upper respiratory Passeiges. Cancer 54 : 907912, 1984.

5）小村 堡，武宮三三。田男之，田田耿子，小野 再、

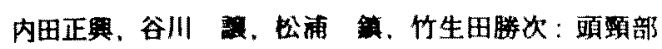

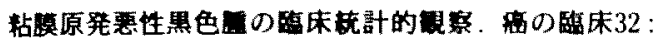
$1511-1518,1986$.

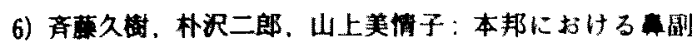

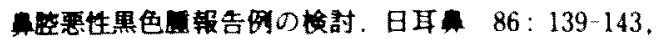
1983.

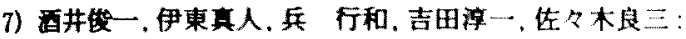

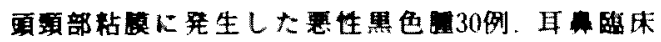
78: 2799-2812, 1985.

8) Ballantyne AJ : Malignant Melanoma of the Skin of the Head and Neck. The American Journal of Surgery $120: 425-431,1970$.

9) Batsakis JG, Regezi JA, Solomon AR, Rice DH : The Pathology Of Head and Neck Tumors: Mucosal Melanomas, Part 13. Head and Neck Surg 4: $404-412,1982$

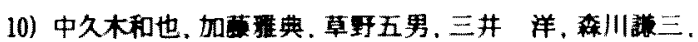

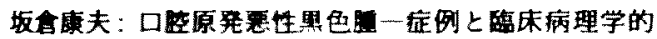
考察一。耳留照床 $70: 953-969 ， 1977$.

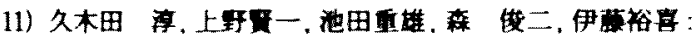

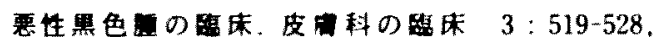
1961 .

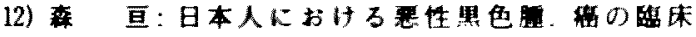
$17: 245-246,1971$

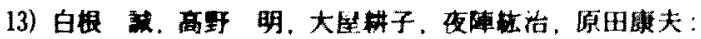

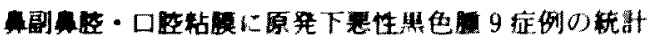

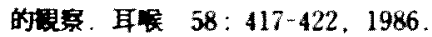

14) Lee SP, Shimizu KT, Tran LM, Juillard G, Calcaterra TC: Mucosal Melanoma of Head and Neck: The Impact of Local Control on Survival.
Laryngoscope 104:121-126, 1994.

15) Freedmann HM, DeSanto LW, Devine KD, Weiland LH. Minn R: Malignant Melanoma of the Nasal Cavity and Paranasal Sinuses. Arch Otolaryngol $97: 322-325,1973$

16) Rosenberg SA, Packard BS, Aebersold PM, Solomon D, Topalianm SL, et al: Use of tumorinfiltrating lymphocytes and interleukin -2 in the immunotherapy of patients with metastatic melanoma, a preliminary report. N Eng J Med 319 : $1676-1680,1988$.

17) Kingdom TT, Kaplan MJ : Mucosal melanoma of the nasal cavity and paranasal sinuses. HEAD \& NECK 17: 184 189, 1995.

18) Del Prete SA, Maurer LH,O'Donnell J, Forcier RJ, LeMarbre $P$ : Combination chemotherapy with cisplatin, carmustin, dacarbazine and tamoxifen in metastatic melanoma. Cancer Treat Rep 68: 14031405, 1984

19) McClay EF, Mastrangelo MJ, Sprandio JD, Bellet RE, Berd D: The importance of tamoxifen to a cisplatin containing regimen in the treatment of metastatic melanoma. Cancer 63: 1292-1295, 1989.

20) Atkins MB, O'Boyle KR. Sosman JA, Weiss GR. Margolin KA et al: Multiinstitutional Phase II Trial of Intensive Combination Chemoimmunotherapy for Metastatic Melanoma. J of Clinical Oncology 12: 1553-1560. 1994.

(1995年11月8日受䊈 1996年1月11日受理)

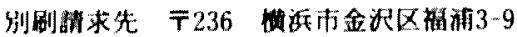

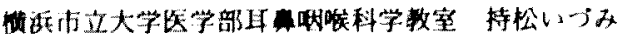




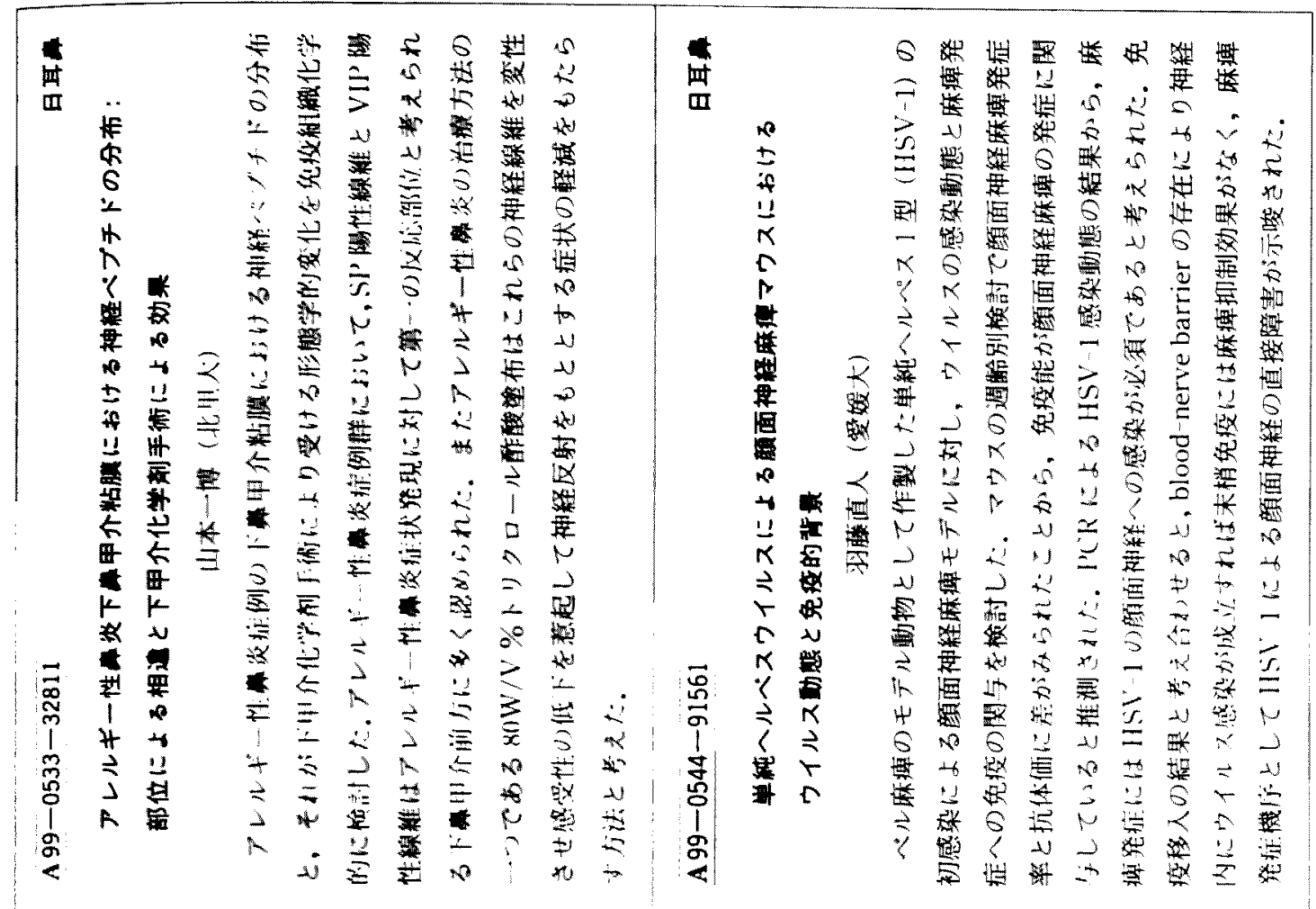

\begin{tabular}{|c|c|c|c|c|c|c|c|c|c|c|c|c|c|c|c|c|c|c|c|c|c|c|}
\hline $\mid$\begin{tabular}{l}
2 \\
9 \\
\hdashline \\
1 \\
$\infty$ \\
4 \\
$\vdots$ \\
1 \\
1 \\
2 \\
2
\end{tabular} & 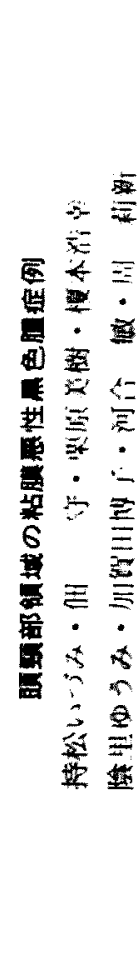 & 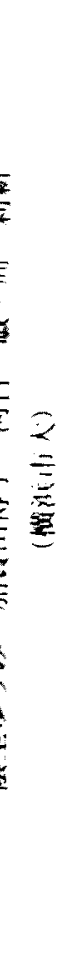 & 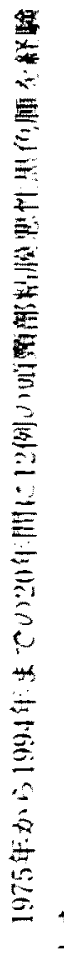 & $\begin{array}{ll} \\
3 \\
0\end{array}$ & 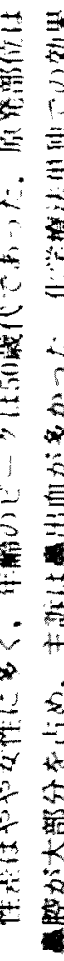 & 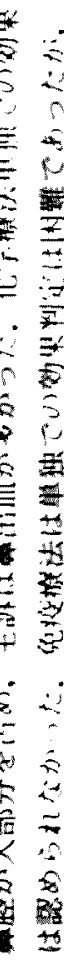 & 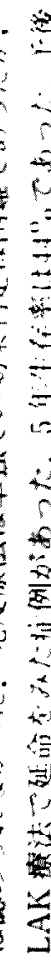 & 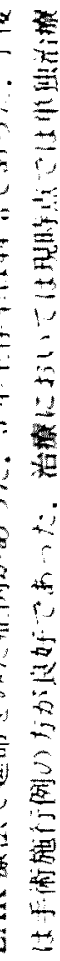 & 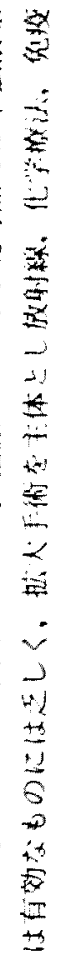 & 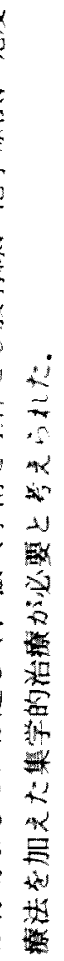 & & 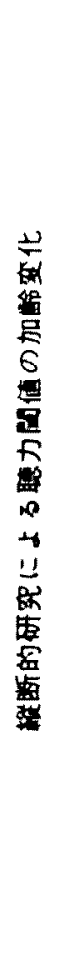 & 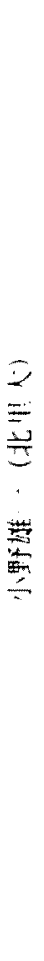 & 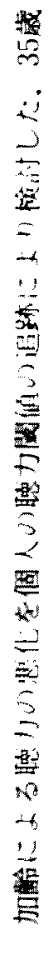 & 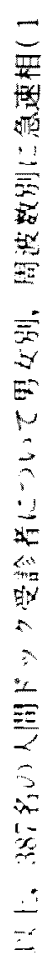 & 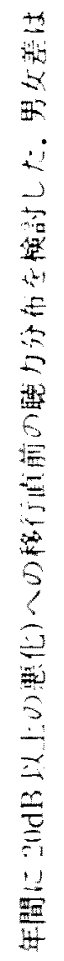 & 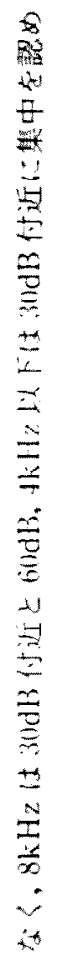 & 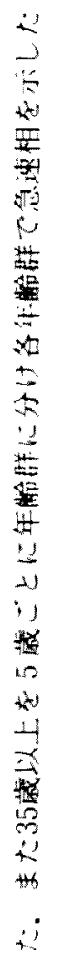 & 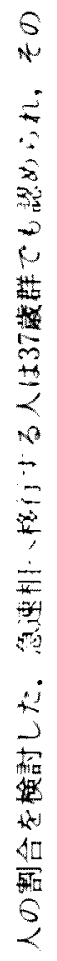 & 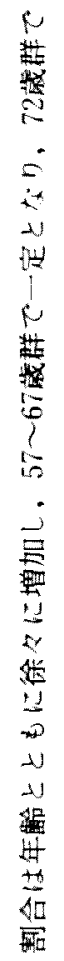 & 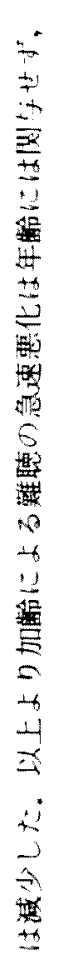 & 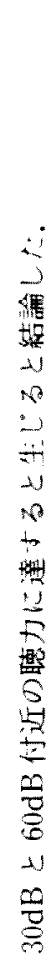 \\
\hline
\end{tabular}

